\title{
PENDIDIKAN NONFORMAL DAN PENGURANGAN KEMISKINAN DI PEDESAAN
}

\author{
Entoh Tohani \\ Universitas Negeri Yogyakarta \\ e-mail: tohani.entds@yahoo.com
}

\begin{abstract}
Non-formal education through life skills education has shown a positive contribution to poverty reduction in rural development efforts, although still requiring efforts to life skills education development. The research was conducted in Kulonprogo, and the District of Gunungkidul, with research and development approach on life skills education programs are being implemented in two districts e.i KWK Rabbits Livestock in Gunungkidul and KWD Hair Dressers in Kulonprogo. The results showed that: life skills education needs assessment in the two target groups were performed using the idea of life skills 4-H shows are not much different conditions, and based on the needs of the development, 4-H life skills education model developed with a focus on experience-based learning. Development of validated models show the results (output) is positive. Therefore, in the context of poverty reduction in 4-H PKH models should be developed more structured and integrative and guarantee all the life skills that are the focus of life skills development efforts to overcome poverty.

$* * *$

Pendidikan non-formal melalui pendidikan ketrampilan telah menunjukkan kontribusi positif terhadap penurunan angka kemiskinan dalam pembangunan pedesaaan. Penelitian ini dilaksanakan di Kulonprogo dan Gunung Kidul dengan pendekatan penelitian dan pengembangan yang diimplementasikan di kelompok peternakan kelinci di Gunungkidul dan di kelompok perawatan rambut di Kulonprogo. Hasilnya menunjukkan bahwa: estimasi kebutuhan pendidikan ketrampilan di dua kelompok target yang dilaksanakan dengan menggunakan ide tentang life skill 4-H menunjukkan kondisi yang tidak jauh berbeda, model life skill 4-H dikembangkan dengan fokus pembelajaran berbasis pengalaman. Pengembangan model validasi memberikan hasil positif. Oleh karena itu dalam konteks penurunan angka kemiskinan dalam model PKH 4-H harus dikembangkan secara lebih terstruktur dan integratif serta menjamin semua pendidikan ketrampilan berorientasi pada penanganan kemiskinan.
\end{abstract}

Keywords: model, life skill, pendidikan nonformal, kemiskinan 


\section{A. Pendahuluan}

Perkembangan pendidikan nonformal selalu berkait dengan upaya pengurangan kemiskinan di pedesaan salah satunya melalui pendidikan kecakapan hidup atau secara terbatas melalui pendidikan vokasional. ${ }^{1}$ Dalam batas-batas tertentu, pendidikan kecakapan hidup itu telah menunjukkan perannya dalam pengentasan kemiskinan di pedesaan meskipun masih ditemui ada beberapa kekurangan terutama dalam hal perancangan dan pelaksanaan program. ${ }^{2}$ Pendidikan kecakapan hidup di dua kabupaten yaitu Kabupaten Gunungkidul, dan Kulonprogo telah menunjukkan dapat berperanan dalam mengurangi angka kemiskinan di pedesaan sekitar 3-6\% dari keseluruhan peserta program pendidikan kecakapan hidup yang dilaksanakan di dua kabupaten tersebut.

Untuk mengembangkan pendidikan kecakapan hidup sebagai salah satu bentuk pendidikan nonformal yang melandasi berbagai bentuk pendidikan nonformal yang lainnya perlu dilakukan upaya penelitian dan pengembangan berbagai model program pendidikan kecakapan hidup yang memiliki kontribusi bagi pengurangan kemiskinan di pedesaan. Penelitian ini dilaksanakan untuk memenuhi dan memperkaya tersedianya berbagai model program pendidikan kecakapan hidup yang mampu memenuhi perannya dalam pengembangan pendidikan nonformal dalam rangka mengurangi kemiskinan di pedesaan.

\section{B. Life Skill}

Kecakapan hidup adalah kecakapan yang dimiliki seseorang untuk berani menghadapi masalah-masalah hidup dan kehidupan dengan wajar tanpa merasa cemas, tertekan, kemudian secara proaktif dan kreatif mencari serta menemukan solusi sehingga akhirnya mampu mengatasinya dalam rangka mewujudkan kehidupan yang sejahtera. Kecakapan hidup perlu dikuasai oleh setiap warga masyarakat dalam menghadapi tantangan perubahan kehidupan yang mengandung berbagai persaingan yang ketat dalam memenuhi kebutuhan hidup.

1 Francis, M., "Life Skills Education," (2007), http://www.changingminds.org diakses pada tanggal 5 April 2010.

2 Yoyon Suryono, Evaluasi Implementasi Pendidikan Kecakapan Hidup dalam Mengurangi Kemiskinan di Pedesaan, (Yogyakarta: Lembaga Penelitian UNY, 2009). 
Suatu model kecakapan hidup yang baru-baru ini dikembangkan adalah model kecakapan hidup 4-H yaitu head, hand, heart, and health atau otak, tangan, hati, dan sehat. Model kecakapan hidup ini dikembangkan pertama kali oleh Universitas Ohio, Amerika Serikat. Pada dasarnya, model ini dikembangkan atas dasar pemahaman bahwa manusia dalam rangka mengatasi permasalahan hidup, dan sekaligus memenuhi kebutuhan hidupnya tidak akan tercapai apabila salah satu atau semuanya di antara kemampuan berpikir, kemampuan bekerja, kemampuan mengelola jiwa/hati, dan kualitas kesehatan tidak dalam kondisi yang diharapkan.

Model kecakapan hidup (life skills) yang dimaksud dideskripsikan sebagai berikut:

Tabel 1.

Deskripsi Life Skills 4-H

\begin{tabular}{|l|l|}
\hline \multicolumn{1}{|c|}{ Kecakapan hidup } & \multicolumn{1}{c|}{ Kompetensi } \\
\hline $\begin{array}{l}\text { OTAK [HEAD] } \\
\text { Pengetahuan, penalaran, } \\
\text { kreativitas }\end{array}$ & $\begin{array}{l}\text { BERPIKIR: melahirkan gagasan, membuat ke- } \\
\text { putusan, mencari penjelasan } \\
\text { PENGELOLAAN: pemanfaatan sumberdaya } \\
\text { untuk mencapai tujuan }\end{array}$ \\
\hline HATI [HEART] & $\begin{array}{l}\text { RELASI: membangun komunikasi yang meng- } \\
\text { untungkan semua pihak } \\
\text { PEDULI: pemahaman, kebaikan hati, dan } \\
\text { afeksi terhadap orang lain. }\end{array}$ \\
\hline $\begin{array}{l}\text { TANGAN [HANDS] } \\
\text { Kejuruan, dan kewargaan } \\
\text { negara }\end{array}$ & $\begin{array}{l}\text { MEMBERI, menyediakan, menjadikan. } \\
\text { BEKERJA, mengupayakan, menghasilkan pen- } \\
\text { dapatan }\end{array}$ \\
\hline $\begin{array}{l}\text { SEHAT [HEALTH] } \\
\text { Kesehatan, kejasmanian }\end{array}$ & $\begin{array}{l}\text { GAYA HIDUP SEHAT, perbuatan, perilaku } \\
\text { KEDIRIAN, pengembangan pribadi, meng- } \\
\text { aktualisasikan diri }\end{array}$ \\
\hline
\end{tabular}

Terkait pemahaman di atas, kecakapan hidup perlu dibentuk dan dikembangkan melalui proses pendidikan yang disebut dengan pendidikan kecakapan hidup. Pendidikan kecakapan hidup adalah upaya untuk meningkatkan keterampilan, pengetahuan, sikap dan kemampuan yang memungkinkan 
warga belajar dapat hidup mandiri. Dalam penyelenggaraan pendidikan kecakapan hidup didasarkan pada prinsip empat pilar pendidikan, yaitu belajar untuk memperoleh pengetahuan (learning to know) yang diikuti oleh belajar untuk mengetahui cara belajar (learning to learn), belajar untuk melakukan pekerjaan (learning to do), belajar agar dapat menjadi orang yang berguna (learning to be) dan belajar untuk hidup bersama dengan orang lain (learning to live together).

Pelaksanaan program pendidikan kecakapan hidup harus dilakukan dengan pengelolaan yang tepat baik perencanaan, pengelolaan dan evaluasinya. ${ }^{3}$ Pada tataran pembelajaran, ciri pempelajaran kecakapan hidup adalah: (1) terjadinya proses identifikasi kebutuhan belajar; (2) terjadinya proses penyadaran untuk belajar bersama; (3) terjadinya keselarasan kegiatan belajar untuk mengembangkan diri, belajar, usaha mandiri, usaha bersama; (4) terjadinya proses penguasaan kecakapan personal, sosial, vokasional, akademik, manajerial, kewirausahaan; (5) terjadinya proses pemberian pengalaman dalam melakukan pekerjaan dengan benar, menghasilkan produk bermutu; (6) terjadinya proses interaksi saling belajar dari ahli; (7) terjadinya proses penilaian kompetensi, dan (8) terjadinya pendampingan teknis untuk bekerja dan membentuk usaha bersama. ${ }^{4}$ Dengan demikian program pendidikan kecakapan hidup perlu dilakukan oleh pengelola yang memiliki kemampuan yang profesional dan perlu memiliki kemampuan berpikir kritis dan kreatif untuk memudahkan mencari upaya penyelesaian masalah yang dihadapi dalam pengelolan program pendidikan kecakapan hidup.

\section{Pengembangan Model Pendidikan}

Pengembangan model pendidikan kecakapan hidup dilakukan dalam dua tahap yaitu: (1) kegiatan pengkajian mengenai kebutuhan kecakapan hidup yang dialami oleh kelompok sasaran, dan (2) mendasarkan pada temuan tersebut, dilakukan pengembangan model pendidikan kecakapan. Dalam pelaksanaan penelitian ini kedua aspek tersebut menjadi satu kesatuan.

3 Sumarno, "Konsep dasar Kebijakan Pendidikan Kecakapan Hidup (Kecakapan Hidup)," Jurnal Dinamika Pendidikan, Vol. 10, No. 2, November 2002, FIP UNY Yogyakarta.

${ }^{4}$ Depdiknas, Kecakapan Hidup: Pendidikan Kecakapan Hidup, (Jakarta: Depdiknas, 2003). 
Deskripsi hasil pelaksanaan kegiatan penelitian ini disajaikan dalam pemaparan berikut ini:

\section{Identifikasi Kebutuhan Pendidikan Kecakapan Hidup}

Pengembangan pendidikan kecakapan hidup yang dilakukan dimulai dengan terlebih dahulu melakukan suatu kegiatan identifikasi kebutuhan (needs assessment) mengenai kecakapan-kecakapan hidup yang dimiliki kelompok sasaran. Identifikasi kebutuhan dimaknai sebagai suatu kegiatan mengumpulkan, mengindentifikasi, menelaah, dan menyimpulkan informasiinformasi yang menggambarkan suatu kesenjangan antara apa yang harusnya dicapai dengan suatu yang dimiliki. Informasi ini penting sebagai dasar untuk menentukan perlakukan-perlakukan yang paling tepat dan bermanfaat terhadap pemecahan suatu permasalahan/kesenjangan.

Proses identifikasi kebutuhan kecakapan hidup pada kedua kelompok dimaksud dilakukan dengan cara membagikan angket atau kuesioner kepada setiap anggota program, dan selanjutnya mereka diminta untuk mengisi/ menjawab angket. Kebutuhan kecakapan hidup yang dikenali mengacu pada pemikiran kecakapan hidup 4-H (Head, Hand, Heart, dan Health). Kepala/otak mencakup kemampuan berpikir dan mengelola, hati terdiri kemampuan berhubungan/relasi, tangan mencakup kemampuan memberi dan berkarya, dan sehat terdiri dari kemampuan mengenal diri dan kemampuan hidup yang sehat. Fokus utama pengkajian informasi melalui angket-disertai kegiatan wawancara-adalah mengetahui berbagai profil masing-masing kelompok belajar dalam kepemilikan kecakapan hidup.

\section{OHTS - KULONPROGO}
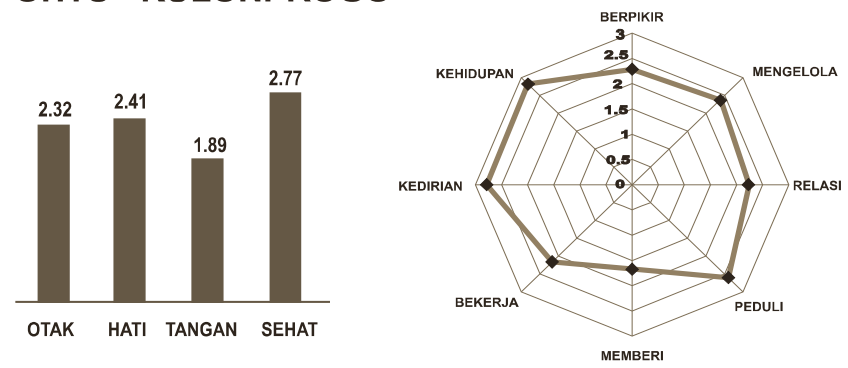

Grafik 1.

Profil LS 4H KWK TKR - Kulonprogo

Walisongo, Volume 19, Nomor 2, November 2011 
Grafik 1 di atas menunjukkan bahwa para peserta pada kelompok belajar pendidikan kecakapan hidup KWK TKR, kecakapan hidup yang masih menunjukkan adanya kebutuhan pendidikan adalah aspek kecakapan hidup terkait dengan aspek tangan yaitu kecakapan bekerja dan kecakapan dalam konteks memberi manfaat kepada orang lain. Dalam skala pengukuran 0 sampai 3, terlihat kecakapan aspek ini masih rendah dibandingkan dengan kecakapan terkait dengan aspek otak, hati, dan kesehatan.

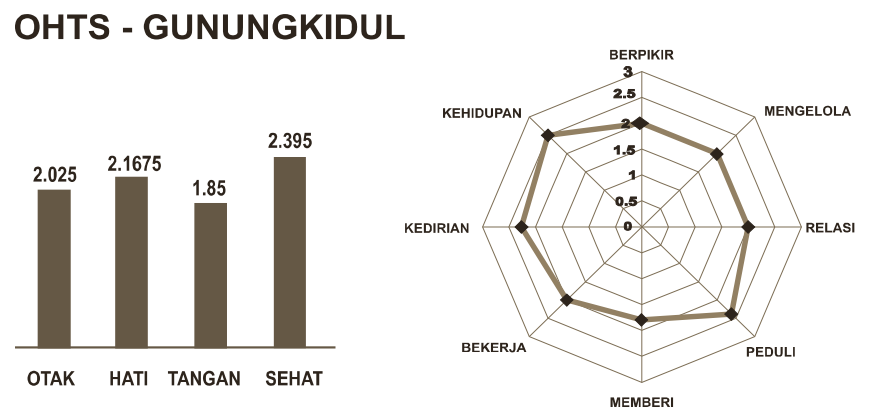

Grafik 2.

Profil $L S 4 H$ KWD - Gunungkidul

Sedangkan profil peserta pada program pendidikan kecakapan hidup KWD ternak kelinci menunjukkan hal yang tidak jauh berbeda. Grafik 2 menampilan informasi bahwa kecakapan hidup yang dimiliki para peserta program dimaksud masih memerlukan pengembangan pada aspek tangan (hands) yaitu bekerja dan member, aspek otak yaitu berpikir dan mengelola dan aspek hati yaitu menjalin relasi. Dengan demikian, dapat dipahami bahwa pada para peserta kedua program yang diobservasi peningkatan kecakapan hidup terkait dengan kemampuan memberi dan bekerja perlu segera dikembangkan.

Mendasarkan pada grafik 1 dan 2 dimaksud tentang kemampuan kecakapan hidup yang dimiliki kelompok sasaran dapat ditarik pemahaman bahwa pada peserta pada kedua program pendidikan kecakapan hidup pada aspek tangan (hands) masih rendah dimiliki. Kemampuan bekerja dan memberi manfaat masih belum optimal dimiliki. Kondisi ini menggambarkan adanya kebutuhan pendidikan guna mengembangkan aspek 4-H terutama aspek tangan. 


\section{Pengembangan Model Pendidikan Kecakapan Hidup}

Proses pengembangan ini dilakukan secara bertahap mengikuti langkahlangkah dalam penelitian dan pengembangan. Adapun rinci setiap tahap pengembangan dan hasil yang dicapai dapat dideskripsikan sebagai berikut:

\section{a. Pengkajian}

Penelitian ini dilaksanakan dengan tahap pertama adalah pengkajian terhadap berbagai sumber kajian mengenai kecakapan hidup dan kajian mengenai proses penyelenggaraan program pendidikan nonformal (PNF). Hasil kajian mengenai kecakapan hidup diperoleh suatu pemahamanan kecakapan hidup yang dapat dikembangkan yaitu model 4-H (head, hands, heart, and health) dan model life skills yang dikembangkan oleh Kementerian Pendidikan Nasional. Sedangkan kajian terhadap penyelenggaraan program PNF di masyarakat menghasilkan informasi mengenai penyelenggaraan berbagai program PNF oleh masyarakat atau lembaga pendidikan seperti KWD dan KWK. Kajian juga dilakukan guna mengetahui pembelajaran yang ada di program PKH yang selama ini dilakukan, dan selanjutnya merumuskan desain pembelajaran yang akan dilakukan dalam kegiatan penelitian ini.

\section{b. Perumusan Model}

Berdasarkan pada hasil kajian pada tahapan di atas, kemudian dirumuskan model pendidikan kecakapan hidup (PKH) sekaligus model pembelajarannya yang dapat diterapkan. Model pendidikan kecakapan hidup yang dirumuskan adalah model pendidikan kecakapan hidup yang dikembangan oleh Universitas Ohio di Amerika Serikat yaitu model 4-H (Head, Hand, Heart, dan Health). Pemilihan model 4-H didasarkan pada pikiran bahwa model ini selama ini belum banyak dikembangan di negara-negara berkembangan termasuk Indonesia dan memiliki unsur inovasi atau kebaruan dimana model life skills 4-H menunjukkan suatu pandangan bahwa seorang individu dalam memenuhi kebutuhan hidupnya perlu mengembangkan berbagai potensi dan kapasitasnya. Manusia yang berkuaitas adalah seseorang yang dapat mengembangkan segenap potensinya baik pikiran, perasaan, keterampilan dan raganya guna mengatasi masalah hidup dan kehidupannya serta memberikan manfaat kepada kesejahteraan keluarga dan masyarakatnya. 
Mendasarkan pada hasil muatan kecakapan hidup yang akan dikembangkan dan penerapan pembelajaran berbasis pengalaman, pada penelitian ini merumuskan suatu model pendidikan kecakapan hidup yang dikembangkan sebagaimana dalam gambar 1.

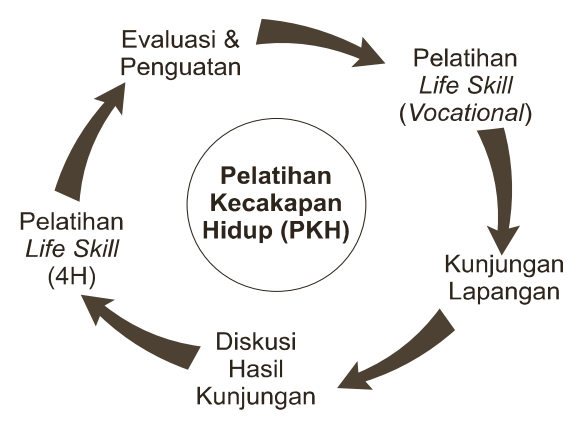

Gambar 1.

Model Pelatihan Life Skills

Gambar 1 menggambarkan siklus pendidikan kecakapan hidup yang dikembangkan meliputi:

1) Pelaksanaan pembelajaran pendidikan kecakapan yang hidup yang diorientasikan pada penguasaan keterampilan yang diperuntukkan menyelesaikan atau melaksanakan pekerjaan (vokasional).

2) Kunjungan lapangan. Setelah pembelajaran vokasional dilakukan, selanjutnya kelompok sasaran pendidikan kecakapan hidup diajak/ diperkenalkan kepada lapangan langsung dengan cara memberikan pengalaman-pengalaman dalam praktek sehari-hari terkait dengan keterampilan vokasional atau kecakapan hidup lainnya

3) Diskusi hasil kunjungan. Kelompok sasaran pendidikan kecapakan hidup diminta untuk merefleksikan dan berbagai pengetahuan dan wawasan kepada warga belajar lainnya dalam suatu forum diskusi yang dilandasi suasana kebersamaan dan kekeluargaan.

4) Pelatihan kecakapan hidup 4-H. Mendasarkan pada diskusi terfokus, selanjutan pelatihan kecakapan hidup akan dilakukan. Model kecakapan hidup yang dikembangkan adakan model 4-H (Head, Hand, Heart, and Health). 
5) Penguatan dan Refleksi. Tahapan terakhir ini dimaksudkan untuk mengetahui keefektifan hasil pelatihan yang diberikan terkait dengan penguasaan keterampilan-keterampilan yang dilatihkan.

Model pendidikan kecakapan hidup yang dirumuskan sebagaimana di atas, sebelum dilakukan ujicoba, dibahas lebih lanjut oleh para ahli pembelajaran nonformal dan ahli pendidikan umumnya untuk mengkaji kevalidan dan kelayakan dari model yang dirumuskan dalam suatu diskusi terfokus.

\section{c. Ujicoba Terbatas Model Pendidikan Kecakapan Hidup}

Model pendidikan kecakapan hidup sebagaimana dijelaskan di atas, dalam penelitian ini diujicobakan secara terbatas pada peserta yang sedang mengikuti program pendidikan kecakapan hidup yaitu program kewirausahan perkotaan (KWK) tata kecantikan rambut yang diselenggarakan Sanggar Kegiatan Belajar (SKB) Kabupaten Kulonprogo, dan program kewirausahaan perdesaan (KWD) yang diselenggarakan PKBM Ngudi Kapinteran Semanu, Kab. Gunungkidul. Pemilihan kedua program tersebut disebabkan oleh ketersediaan sumberdaya yang dimiliki dalam melaksanaan penelitian ini.

Pelaksanaan pengembangan uji coba terbatas pada program KWK TKR secara ringkas dapat dideskripsikan sebagaimana bagan berikut:

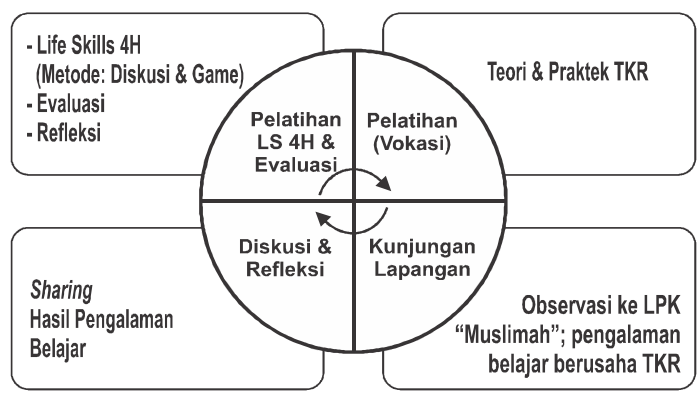

Gambar 2.

Model PKH 4-H pada KWK TKR

Walisongo, Volume 19, Nomor 2, November 2011 
Sedangkan pelaksanaan pengembangan model pendidikan kecakapan hidup yang dilaksanakan pada program KWD ternak kelinci digambarkan berikut:

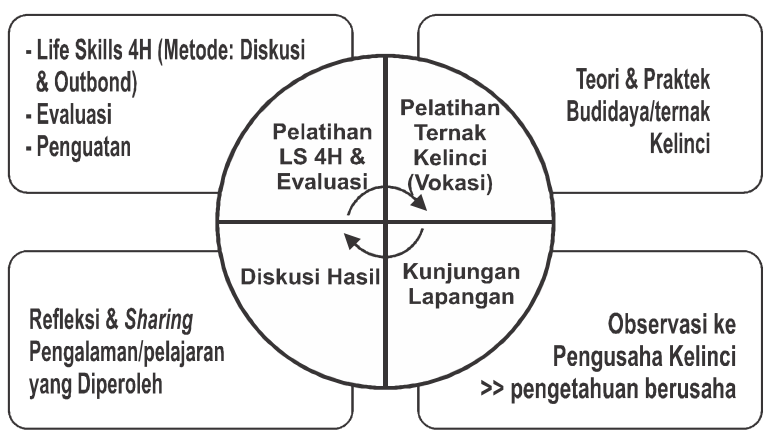

Gambar 3.

Model PKH 4-H pada KWD Kelinci

Pengembangan model pendidikan kecakapan hidup yang dilakukan nampaknya mampu meningkatan pengetahuan atau kecakapan warga belajar (output). Hal ini nampak dari perubahan perilaku peserta program pendidikan, yang mana dengan hasil penilaian pasca pelatihan pada masingmasing program yang dikenai pengembangan model kecakapan hidup 4- $\mathrm{H}$ menunjukkan bahwa warga belajar mengalami perubahan perilaku positif setelah mengikuti pembelajaran dibandingkan dengan perilaku yang dimiliki sebelum mengikuti pembelajaran pendidikan kecakapan hidup model 4-H. Perubahan perilaku dapat dilihat dari aspek-aspek 4-H yang dirinci ke dalam 8 indikator kecakapan hidup 4-H secara keseluruhan sebagaimana dideskripsikan dalam grafik 3 pada halaman berikut.

Pada program KWD kelinci, perubahan perilaku positif yang lebih besar terjadi pada kecakapan hidup berpikir dan dapat memberikan makna berarti guna pengembangan kualitas peserta program pendidikan nonformal mengelola (head), dan menjalin relasi (heart), memberi dan bekerjasama (hands). Sedangkan pada program KWK TKR perubahan perilaku signifikan terjadi kecakapan bekerja sama dan memberi (hands) dan menjalin hubungan (heart). 

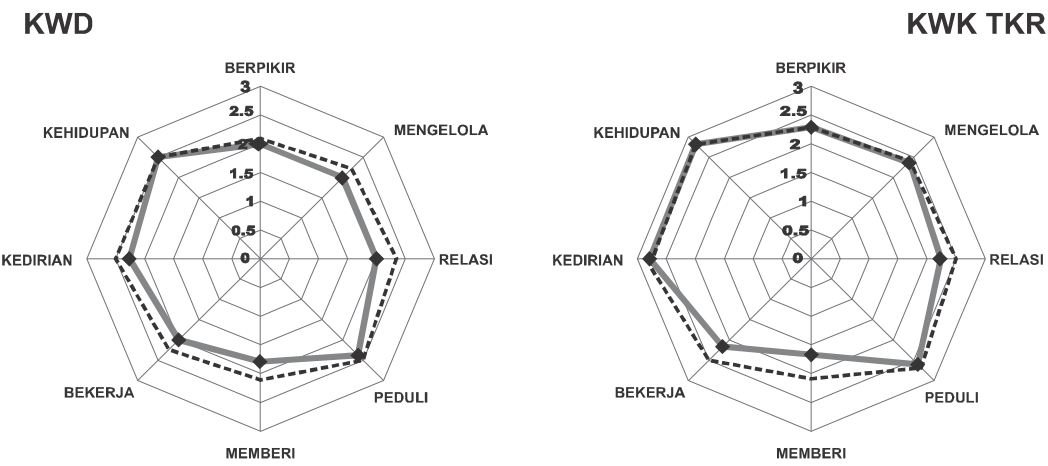

Keterangan:

- : pre-test

\section{Grafik 3.}

Hasil 8 Aspek 4H

Sedangkan perubahan perilaku peserta ditinjau dari keseluruhan 4-H secara umum disajikan dalam grafik 4 berikut. Nampak output belajar yang meningkat dapat dicapai pada kelompok belajar pada kedua program yang dianalisis. Dengan demikian, dapat dikatakan model pendidikan kecakapan hidup yang dikembangkan dapat memberikan makna berarti untuk pengembangan kualitas peserta program pendidikan nonformal.

LS 4H KWH

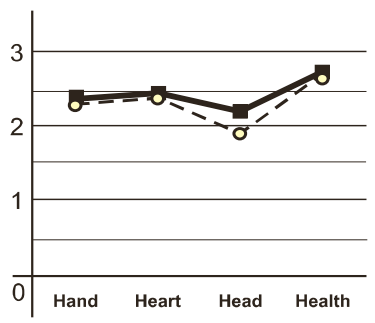

LS 4H KWH
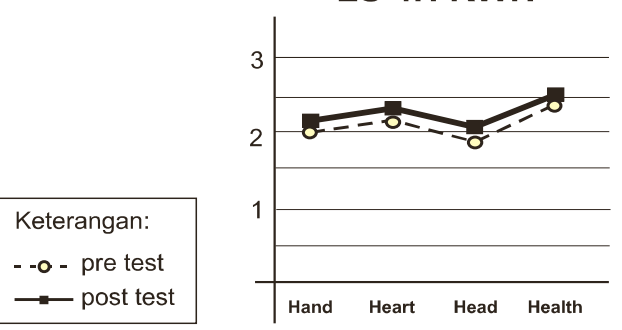

Grafik 4.

Output PKH 4H

Walisongo, Volume 19, Nomor 2, November 2011 


\section{Kesimpulan}

Kegiatan penelitian dilakukan guna menghasilakna keterangan atau informasi mengenai konseptual kecakapan hidup, praksis program kecakapan hidup, perumusan model pendidikan kecapakan hidup yang fesiabel/layak yaitu model pendidikan kecakapan hidup 4-H (head, hands, heart, dan health). dan karakteristik kebutuhan kecakapan hidup pada kelompok sasaran program pendidikan yang dianalisis yaitu KWD ternak kelinci dimana kecakapan khususnya kemampuan kreativitas dan mengelola (head), menjalin relasi (heart), bekerja profesional dan mampu memberi (hands) perlu dikembangkan dan kebutuhan pada kelompok KWK TKR dimana kemampuan mengelola (heads), bekerja dan memberi (hands) juga memerlukan suatu peningkatan. Mendasarkan pada temuan ini, model pendidikan kecakapan hidup yang terumuskan diaplikasikan pada kelompok sasaran tersebut.

Berdasarkan pada hasil tahap pertama, kegiatan pengembangan model kecapakan hidup dilakukan. Model pendidikan kecakapan hidup 4-H merupakan dari serangkai kegiatan yang meliputi pelatihan vokasional, observasi lapangan, diskusi dan refleksi, pelatihan kecakapan hidup 4-H, serta penilaian dan penguatan. Model ini dikembangkan pada kedua kelompok sasaran dengan fokus pengembangan kecakapan hidup sebagaimana informasi yang diperoleh dari tahapan kebutuhan kecakapan hidup pada masingmasing kelompok. Hasil evaluasi dari kegiatan pengembangan model PKH 4$\mathrm{H}$ nampaknya mampu meningkatkan output pembelajaran dimana pada masing-masing kelompok terjadi peningkatan pemahaman/pengetahuan atau kecakapan hidup.

Oleh karena itu, mendasarkan pada temuan tersebut, penelitian dan pengembangan model PKH 4-H dipandang sebagai suatu upaya atau mekanisme yang efektif dan bermanfaat untuk pengembangan berbagai kecakapan-kecakapan hidup yang harus dimiliki oleh individu atau masyarakat sehingga dirinya dapat mengatasi berbagai masalah hidup yang dihadapi terutama dapat melepaskan diri dari kondisi kemiskinan. Model yang dihasilkan diharapkan dapat menjadi acuan dalam memberdayakan masyarakat miskin dalam rangka meningkatkan kualitas sumberdaya insani.[w] 


\section{BIBLIOGRAFI}

Anwar, Pendidikan Kecakapan Hidup, Bandung: Aphabeta, 2004.

Depdiknas, Kecakapan Hidup - Pendidikan Kecakapan Hidup, Jakarta: Depdiknas, 2003.

Fenwich, Tara J., Experiential Learning: A Theoretical Cririque From Five Perspectives, Columbus: The Ohio State University, 2001.

Francis, M., "Life Skills Education,” 2007, http://www.changingminds.org diakses pada tanggal 5 April 2010.

Jurusan PLS FIP UNY, Draft Kurikulum Program Studi S1 PLS, Yogyakarta: Jurusan PLS FIP UNY, 2007.

Miles Matthew B., \& Huberman, A. Michael, Analisis Data Kualitatif, (Terjemahan Tjetjep Rohendi Rohindi). Jakarta: Penerbit Universitas Indonesia, 2007.

Sumarno, Konsep dasar Kebijakan Pendidikan Kecakapan Hidup, Jurnal Dinamika Pendidikan No. 02/TH IX. November 2002 FIP UNY Yogyakarta, 2002.

Valadez \& Bamberger, Monitoring and Evaluating Social Programs in Developing Countires, Washington: The World Bank, 1994.

Yoyon Suryono, Pemanfaatan Pusat Kegiatan Belajar Masyarakat (PKBM) untuk Penyelenggaraan Mata Kuliah Praktek Pembelajaran dan Laboratorium Luar Kampus Program Studi PLS, Yogyakarta: Jurusan PLS FIP UNY, 2000.

Pendekatan Teori 'Social Learning' dalam Pembelajaran Matakuliah Identifikasi Kebutuhan Pendidikan pada Program Studi PLS FIP UNY, Yogyakarta: Jurusan PLS FIP UNY, 2000.

Identifikasi Kebutuhan Pengembangan Lembaga Pendidikan Kejuruan (LPK) di Kota Yogyakarta dalam Rangka Desentralisasi Pendidikan, Yogyakarta: FIP UNY, 2001.

Pengkajian Implementasi Manajemen Berbasis Sekolah (MBS) di SD dan MI di Provinsi DIY, Dinas Pendidikan dan Pengajaran Provinsi DIY, 2001.

Pemetaan Kebutuhan Pengembangan Program Pendidikan Luar Sekolah dengan Pendekatan Perencanaan Strategik di Kecamatan Pajangan 
Kabupaten Bantul sebagai Laboratorium Luar Kampus Program Studi PLS, Yogyakarta: Jurusan PLS FIP UNY, 2002.

Partisipasi Masyarakat dalam Pengembangan Pendidikan Luar Sekolah Melalui Pusat Kegiatan Belajar Masyarakat (PKBM) di Kota Yogyakarta, Yogyakarta: Jurusan PLS, 2003.

Pemetaan Kemampuan Keuangan Daerah dan Masyarakat dalam Membiayai Pendidikan (Kajian Kelayakan Pajak Daerah untuk Pendidikan), Pusat Penelitian Kebijakan Pendidikan, Lembaga Penelitian UNY, 2004.

"Pembelajaran Kratif Kritis Bermuatan Hard-skill dan Soft-skill Mata Kuliah Ilmu Pendidikan," Majalah Ilmiah Pembelajaran, Vol. 3, No. 1, Mei 2007.

Evaluasi Implementasi Pendidikan Kecakapan Hidup dalam Mengurangi Kemiskinan di Pedesaan, Lembaga Penelitian UNY, 2009. 